\title{
Desafios contemporâneos da saúde do trabalhador
}

O Número Temático "Desafios da Saúde do Trabalhador (ST) no Mundo Contemporâneo", da Revista Ciência e Saúde Coletiva (RCSC), ora publicado, é fruto de um processo de trabalho coletivo e produção colaborativa realizada por muitas mãos, o que resultou em um importante e diferenciado compêndio de manuscritos, retrato atual de reflexões, estudos e intervenções da ST no Brasil.

No plano histórico, vive-se no Brasil uma crise sanitária, política e humanitária sem precedentes. A pandemia do novo coronavírus (Sars-CoV-2) já matou 604 mil pessoas e contaminou 21 milhões e 700 mil pessoas, até o momento. Esses números expressam, entre outros aspectos, a dramaticidade da questão social, como aprofundamento da concentração de renda e das desigualdades consequentes. Ademais, o cenário de crise alcançou o mundo do trabalho de forma avassaladora com perdas de direitos e retrocessos de conquistas históricas da classe trabalhadora. Assim, estão comprometidas as formas clássicas de proteção social, como aposentadorias e previdência pública, bem como ampliou o número de acidentes e doenças ocupacionais. Retornaram, com mais força, antigos e novos modos de exploração do trabalho por meio da intensificação da jornada laboral, precarização do trabalho e desemprego estrutural, traços marcantes das estratégias de dominação da classe trabalhadora.

Soma-se a esse cenário desalentador governos conservadores de ultradireita e anticiência que atuam na direção do aumento dos privilégios de classe. Nada exatamente novo, pois tratam-se de estratégias que acentuam as formas de exploração e opressão de raça e gênero, o que contribui para a triste expansão da violência, fome e declínio na qualidade das condições de vida e de saúde da classe trabalhadora ${ }^{1}$. Por outro lado, trabalhadores(as) desenvolvem novos modos de ação e estratégias criativas, individuais e coletivas, para driblar as adversidades do trabalho e se contrapor às ofensivas do capital.

No que tange, especificamente à relação trabalho, saúde e ambiente, compreende-se que o trabalho está associado, permanentemente, à produção de danos à saúde, podendo causar doenças, reduzir a vida profissional e levar à morte do trabalhador quando realizado em condições ambientais inadequadas. Todos os processos de trabalho envolvem situações de risco, que atuam direta ou indiretamente de diferentes formas, como fisiológicas, psicológicas e emocionais, sobre o(a) trabalhador $(a)^{2}$. Importa considerar, ainda, que no plano estrutural as condições ambientais são modificadas de acordo com os interesses e conveniência de reprodução do capital, gerando impactos à saúde e aumento de vulnerabilidades humanas e sociais. Nessa perspectiva, não existe desastre verdadeiramente natural, considerando que natureza, vida e ação humana estão metabolicamente interligados ${ }^{3}$.

Por fim, no que concerne ao processo de edição da presente publicação, registre-se o papel protagonista do Centro de Estudos da Saúde do Trabalhador e Ecologia Humana (CESTEH/ENSP/Fiocruz) que possibilitou o diálogo com instituições e movimentos sociais que integram a grande rede de ST no país. Assim, dos 243 artigos recebidos, chegou-se a 21 manuscritos selecionados que se destacaram por mérito, qualidade e atualidade temática, organizados em torno dos seguintes eixos temáticos: desemprego, informalidade e saúde do trabalhador; formação e comunicação em Saúde do Trabalhador; precarização e intensificação do trabalho; saúde mental e trabalho; vigilância em Saúde do Trabalhador e substâncias químicas nas indústrias e a saúde de trabalhadores e populações.

Agradecemos à RC\&SC pela oportunidade e a todos(as) autores(as) que participaram dessa publicação. Boa leitura!

Kátia Reis de Souza (http://orcid.org/0000-0002-2084-2606) ${ }^{1}$

Gideon Borges dos Santos (https://orcid.org/0000-0003-1179-9404) ${ }^{1}$

Luciana Gomes (https://orcid.org/0000-0003-2038-0859) ${ }^{1}$

Maria de Fátima Ramos Moreira (https://orcid.org/0000-0002-4521-1050) ${ }^{1}$

Renato Bonfatti (https://orcid.org/0000-0002-0924-5149) ${ }^{1}$

Rosângela Brito (https://orcid.org/0000-0003-0138-8484) ${ }^{1}$

${ }^{1}$ Centro de Estudos da Saúde do Trabalhador e Ecologia Humana, Escola Nacional de Saúde Pública Sergio Arouca, Fundação Oswaldo Cruz. Rio de Janeiro RJ Brasil.

\section{Referências}

1. Granemann S. Crise econômica e a Covid-19: rebatimentos na vida (e morte) da classe trabalhadora brasileira. Trab Educ Saude 2021; 19:e00305137.

2. Agostini M. Saúde do Trabalhador. In: Andrade A, Pinto SC, Oliveira RS, organizadores. Animais de Laboratório: criação e experimentação. Rio de Janeiro: Editora Fiocruz; 2002. p. 375-379.

3. Harvey D. Anticapitalismo em tempos de pandemia. São Paulo: Boitempo; 2020. 